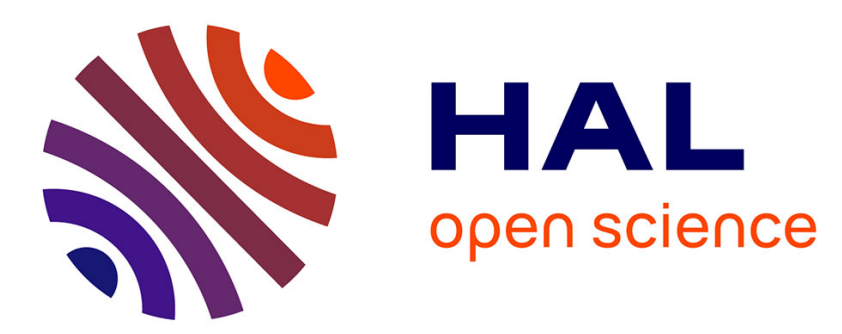

\title{
Cyclic oxidation of AISI 316L stainless steel - influence of water vapour between 800 and $1000^{\circ} \mathrm{C}$
}

\author{
Henri Buscail, R. Rolland, S. Perrier
}

\section{To cite this version:}

Henri Buscail, R. Rolland, S. Perrier. Cyclic oxidation of AISI 316L stainless steel - influence of water vapour between 800 and $1000^{\circ}$ C. Corrosion Engineering, Science and Technology, 2014, 49 (3), pp.169 - 179. 10.1179/1743278213Y.0000000111. hal-01628821

\section{HAL Id: hal-01628821 \\ https://hal.science/hal-01628821}

Submitted on 4 Nov 2017

HAL is a multi-disciplinary open access archive for the deposit and dissemination of scientific research documents, whether they are published or not. The documents may come from teaching and research institutions in France or abroad, or from public or private research centers.
L'archive ouverte pluridisciplinaire HAL, est destinée au dépôt et à la diffusion de documents scientifiques de niveau recherche, publiés ou non, émanant des établissements d'enseignement et de recherche français ou étrangers, des laboratoires publics ou privés. 


\title{
Cyclic oxidation of AISI 316L stainless steel - influence of water vapour between 800 and $1000^{\circ} \mathrm{C}$
}

\section{H. Buscail*, R. Rolland and S. Perrier}

\begin{abstract}
At 800 and $900^{\circ} \mathrm{C}, 10$ vol.- $\% \mathrm{H}_{2} \mathrm{O}$ in air has little effect on the AISI $316 \mathrm{~L}$ stainless steel oxidation under isothermal and cyclic conditions. The oxide scale is composed of $\mathrm{Cr}_{2} \mathrm{O}_{3}$ with a small amount of $\mathrm{Mn}_{1.5} \mathrm{Cr}_{1.5} \mathrm{O}_{4}$ at the external interface. Results show that water molecules or protons can modify the diffusion process in the scale and lower the oxidation rate. At $1000^{\circ} \mathrm{C}$, a deleterious effect of water vapour on the scale structure is observed. In situ X-ray diffraction was used to analyse the oxide formation on AISI $316 \mathrm{~L}$ specimens during isothermal oxidation at $1000^{\circ} \mathrm{C}$ in moist air. Results show that the breakaway oxidation is due to the iron oxidation starting after $31 \mathrm{~h}$ oxidation. This leads to an external $\mathrm{Fe}_{2} \mathrm{O}_{3}$ scale growth and an internal multilayered $\mathrm{FeCr}_{2} \mathrm{O}_{4}$ scale formation. In wet air, thermal cycling conditions lead to continuous weight losses at $1000^{\circ} \mathrm{C}$, whereas the scale remains adherent in dry air.
\end{abstract}

Keywords: Water vapour, Oxidation, AISI 316L, In situ X-ray diffraction, Thermal cycling

\section{Introduction}

The AISI 316L austenitic stainless steel (SS) is widely used in industrial applications due to its good creep properties and the oxidation resistance provided by the alloy chromium content. ${ }^{1-8}$ Several studies proposed that, at high temperature, chromia forming alloys such as AISI 316L SS exhibit an oxide growth leading mainly to $\mathrm{Cr}_{2} \mathrm{O}_{3}$ and spinel type oxide formation. ${ }^{9-11}$ It has also been demonstrated that yttria addition leads to an increased oxidation resistance at $800^{\circ} \mathrm{C}^{12}$ The role of molybdenum on the AISI 316L SS oxidation process has been already discussed. It has been demonstrated that molybdenum plays a similar protective role as the one provided by silicon. In dry air, it hinders iron oxidation and leads to a better keying of the chromia scale in the alloy. ${ }^{13-15}$ Water vapour is present in many industrial gases. It is a constituent of combustion gases and can affect high temperature corrosion of heat exchangers or engines. Many investigations have been conducted to increase solid oxide fuel cell performance and increase the corrosion resistance of metallic interconnects. ${ }^{16,17}$ Water vapour is also present in power generation systems, and increasing service temperatures lead to heavy corrosion problems. Water vapour effects have already been described in the literature. ${ }^{18-21}$ Several studies were conducted on chromia forming alloys. ${ }^{22-26}$ In general, water vapour has a major effect on the growth rate of oxide scales. Increasing the amount of water vapour in the atmosphere reduces the Clermont Université, LVEEM, Laboratoire Vellave sur P'Elaboration et l'Etude
des Matériaux, rue Lashermes, BP 70219, Le Puy-en-Velay 43006, France

*Corresponding author, email buscail @iut.u-clermont1.fr time to onset of breakaway oxidation. ${ }^{27}$ Galerie et al. have explained that the breakaway on $\mathrm{Fe}-15 \mathrm{Cr}$ alloy was induced by the rapid growth of hematite at the metal/chromia interface, at $800-1000^{\circ} \mathrm{C}$, in $\mathrm{Ar}-15 \mathrm{H}_{2} \mathrm{O}^{23}$ But in many cases, the chromia scale failure was related to the formation of $\mathrm{CrO}_{2}(\mathrm{OH})_{2}$ and $\mathrm{Cr}(\mathrm{OH})_{3}$ volatile hydroxides. ${ }^{28-30}$ Evaporation can lead to alloy chromium depletion, resulting in the formation of an iron rich non-protective scale. Young proposed that water vapour affects chromia scale growth similarly to what is observed with reactive element metals.$^{31}$ Both segregate to oxide grain boundaries. Grain boundary cation diffusion is then largely suppressed, increasing the oxygen internal diffusion and refining the oxide grain structure. On the other hand, he also explained that in short term laboratory experiments at temperatures above $800^{\circ} \mathrm{C}$, chromium volatilisation could usually be neglected, even in $\mathrm{O}_{2} / \mathrm{H}_{2} \mathrm{O}$ gas mixtures. Refining of the oxide grain structure under wet conditions has also been observed by Jacob et al. after pure chromium oxidation. ${ }^{32}$ Recently, Othman et al. proposed that water vapour has no significant effect if a large chromium reservoir induces the growth of a continuous $\mathrm{Cr}_{2} \mathrm{O}_{3}$ scale layer. ${ }^{33}$ The ability of $\mathrm{Fe}-\mathrm{Cr}$ alloys to form a protective oxide scale was related to the chromium concentration at the alloy surface. When the concentration of chromium is too low, iron rich oxides form, inducing breakaway oxidation. Rahmel et al. suggested that an $\mathrm{H}_{2} / \mathrm{H}_{2} \mathrm{O}$ gas mixture can be formed in voids within the scale then facilitating rapid inward transport of oxygen. ${ }^{18}$ From the literature review, it can be stated that owing to its relatively high chromium content and alloying elements, the AISI $316 \mathrm{~L} \mathrm{SS}$ is oxidation resistant at temperatures up to $1000^{\circ} \mathrm{C}$ in dry environments 

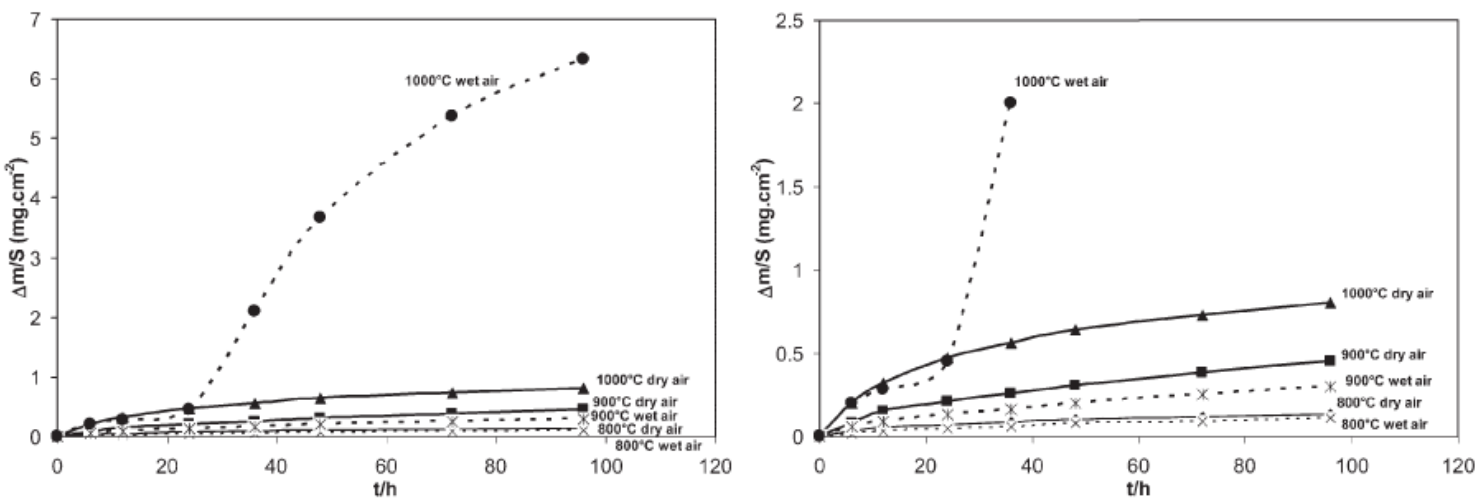

1 Mass gain curves obtained after $96 \mathrm{~h}$ isothermal oxidation of $\mathrm{AISI} 316 \mathrm{~L}$ SS under dry air and wet air (10 vol.- $\left.\% \mathrm{H}_{2} \mathrm{O}\right)$ at 800,900 and $1000^{\circ} \mathrm{C}$

and in isothermal conditions. The aim of the present work is to determine the effect of water vapour on the oxidation mechanism of the AISI 316L SS. In situ X-ray diffraction (XRD) in flowing moist air $\left(10\right.$ vol.- $\left.\% \mathrm{H}_{2} \mathrm{O}\right)$ will provide useful information on the oxidation process. It will be determined if a change in the structural composition of the layer occurs during the oxidation test and if oxide phase transitions occur during cooling to room temperature. The effect of water vapour on the oxide scale adherence will be evaluated by thermal cycling tests at 800,900 and $1000^{\circ} \mathrm{C}$.

\section{Experimental}

The material used in the present work was an AISI $316 \mathrm{~L}$ austenitic SS. The alloy composition is $\mathrm{Fe}-17 \cdot 7 \mathrm{Cr}-$ $10 \cdot 9 \mathrm{Ni}-2 \cdot 16 \mathrm{Mo}-1 \cdot 57 \mathrm{Mn}-0 \cdot 55 \mathrm{Si}-0 \cdot 023 \mathrm{C} \quad$ (wt- $\%)$. The specimens, provided by ArcelorMittal-Imphy, were polished on $\mathrm{SiC}$ paper up to the 800 polishing grade, then washed with ethanol and finally dried prior to isothermal oxidation at 800,900 and $1000^{\circ} \mathrm{C}$. The specimens are $1.5 \mathrm{~mm}$ thick and show a total surface area of $\sim 6 \mathrm{~cm}^{2}$. The kinetic results obtained under isothermal conditions were recorded during $96 \mathrm{~h}$ using a Setaram TG-DTA 92-1600 microthermobalance. The in situ characterisation of the oxide scales was carried out in a high temperature MRI chamber adapted on an Xray Philips $X^{\prime}$ PERT MPD diffractometer (copper radiation, $\lambda k_{\alpha}=0 \cdot 154 \mathrm{~nm}$ ). The diffraction patterns are registered every hour at $1000^{\circ} \mathrm{C}$ in 10 vol. $-\% \mathrm{H}_{2} \mathrm{O}$ flowing air. The XRD conditions were $2 \Theta$ scan, step of $0 \cdot 02^{\circ}$, range from 10 to $80^{\circ}$ and $3 \mathrm{~s}$ counting time. The morphology of the external interface as well as the crosssections was observed using a JEOL JSM-7600F SEM. The analysis of the scale was performed with a LINK energy dispersive X-ray spectroscopy (EDXS). The EDXS point analyses were performed with an electron probe focused to a $1 \mu \mathrm{m}$ spot. The water vapour experiments were performed in air containing $10 \mathrm{vol}$. $-\% \mathrm{H}_{2} \mathrm{O}$. The flowing air $\left(8 \mathrm{~L} \mathrm{~h}^{-1}\right.$ flowrate $)$ is saturated through boiling water. Then, the water bath humidifier maintained at $50^{\circ} \mathrm{C}$ controls the water vapour ratio by condensation of the excess water vapour. All the connecting tubes are maintained at $100^{\circ} \mathrm{C}$ in order to avoid any water condensation out of the furnaces. A schematic drawing of the rig is provided in a previous paper. ${ }^{34}$ Similar gas humidifiers were used either for TGA, wet in situ XRD (MRI chamber) and thermal cycling tests in a tubular furnace. Dry air testing was performed in flowing air at atmospheric pressure. Dry and wet thermal cycling tests were performed at atmospheric pressure in a tubular furnace adapted for oxidation under dry or wet air. Three samples were placed at the same time into an alumina crucible to estimate the reproducibility. The thermal cycles consist of $23 \mathrm{~h}$ exposure at high temperature, followed by $1 \mathrm{~h}$ at ambient temperature after air quenching. The weight change of the samples was determined after each cycle on a balance with an accuracy of $0.01 \mathrm{mg}$. After each cycle, the specimens are weighted out of the crucible in order to measure the net weight change of the specimen.

\section{Results}

\section{Isothermal kinetics}

The mass gain curves per unit area are given in Fig. 1. All isothermal thermogravimetric analyses were carried out during $96 \mathrm{~h}$ at 800,900 and $1000^{\circ} \mathrm{C}$ in ambient air and wet air $\left(10\right.$ vol. $\left.-\% \mathrm{H}_{2} \mathrm{O}\right)$. A parabolic regime was observed throughout the $96 \mathrm{~h}$ oxidation tests except when testing at $1000^{\circ} \mathrm{C}$ in wet air. The $k_{\mathrm{p}}$ values are given in Table 1 . At $800^{\circ} \mathrm{C}$, the oxidation rates are similar under dry and wet air. At $900^{\circ} \mathrm{C}$, the oxidation rate is slightly higher in dry air than in wet air. At $1000^{\circ} \mathrm{C}$, a parabolic regime is followed in dry air, whereas in wet air, 10 vol.- $\%$ water vapour induces an important increase in the oxidation rate after $30 \mathrm{~h}$ oxidation. At $1000^{\circ} \mathrm{C}$, the oxidation rate recorded before the breakaway regime is similar in wet air and dry air.

Table $1 \boldsymbol{k}_{\mathrm{p}}$ values obtained on AISI $316 \mathrm{~L}$ SS after dry air and wet air $\left(10 \mathrm{vol} . \% \mathrm{H}_{2} \mathrm{O}\right)$ oxidation between 800 and $1000^{\circ} \mathrm{C}$

\begin{tabular}{|c|c|c|}
\hline Temperature $/{ }^{\circ} \mathrm{C}$ & $k_{\mathrm{p}}$ dry air $/ \mathrm{g}^{2} \mathrm{~cm}^{-4} \mathrm{~s}^{-1}$ & $k_{\mathrm{p}}$ wet air $/ \mathrm{g}^{2} \mathrm{~cm}^{-4} \mathrm{~s}^{-1}$ \\
\hline $\begin{array}{l}800 \\
900 \\
1000\end{array}$ & $\begin{array}{l}4 \cdot 8 \pm 0 \cdot 1 \times 10^{-14} \\
5 \cdot 8 \pm 0 \cdot 1 \times 10^{-13} \\
1 \cdot 9 \pm 0 \cdot 1 \times 10^{-12}\end{array}$ & $\begin{array}{l}3.5 \pm 0.1 \times 10^{-14} \\
2 \cdot 6 \pm 0.1 \times 10^{-13} \\
2.5 \pm 0.1 \times 10^{-12} \text { (before } 24 \mathrm{~h} \text { ) }\end{array}$ \\
\hline
\end{tabular}




\section{Thermal cycling kinetics}

In Fig. 2, mass changes registered during thermal cycling tests show that at 800 and $900^{\circ} \mathrm{C}$ the mass gain is slightly lower in wet air compared to dry conditions. In these conditions, no scale spallation was observed on the surface after each cycle. It should be noticed that weight gains were already lower under wet isothermal conditions. At $1000^{\circ} \mathrm{C}$, the oxide scale remains adherent in dry air. Very important weight losses are registered in wet air after the second $(23+1 \mathrm{~h})$ cycle at $1000^{\circ} \mathrm{C}$. It should be pointed out that two cycles correspond to $46 \mathrm{~h}$ oxidation, which is more than the $31 \mathrm{~h}$ oxidation preceding the breakaway oxidation observed under isothermal conditions in Fig. 1.

\section{Scale morphology after isothermal oxidation}

The morphology of the scale formed on the AISI 316L SS oxidised isothermally during $96 \mathrm{~h}$ in dry and wet air is presented in Fig. 3. No spalled areas were observed on the surface after dry air oxidation. Energy dispersive Xray spectroscopy analysis of the sample surface shows the presence of manganese, chromium and oxygen $\left(\mathrm{Mn}_{1.5} \mathrm{Cr}_{1.5} \mathrm{O}_{4}\right.$ and $\left.\mathrm{Cr}_{2} \mathrm{O}_{3}\right)$. After wet air oxidation, the scale is still adherent at 800 and $900^{\circ} \mathrm{C}$. The scale surface shows a convoluted aspect after oxidation at $900^{\circ} \mathrm{C}$ in wet air. Energy dispersive X-ray spectroscopy analysis of the sample surface also shows the presence of manganese, chromium and oxygen at 800 and $900^{\circ} \mathrm{C}$. At $1000^{\circ} \mathrm{C}$ in dry air, EDXS analyses show the presence of manganese, chromium and oxygen. At $1000^{\circ} \mathrm{C}$, in wet air, EDXS analyses indicate the presence of chromium, oxygen and iron corresponding to the $\mathrm{FeCr}_{2} \mathrm{O}_{4}$ formation. Scanning electron microscope examinations were carried out on the specimen cross-section (Fig. 4) in order to estimate the scale thickness and to identify the elements constituting the oxide scale. After $96 \mathrm{~h}$ oxidation in dry and wet air at 800 and $900^{\circ} \mathrm{C}$ and in dry air at $1000^{\circ} \mathrm{C}$, the scale is adherent. The EDXS analyses performed on the cross-section show that manganese is located at the scale/gas interface. The middle part of the oxide scale is mainly composed of chromia. Some internal silicon oxidation is observed along the alloy grain boundaries at temperatures higher than $800^{\circ} \mathrm{C}$. No influence of water vapour is observed on the silicon internal oxidation process. Nevertheless, it appears that in wet air the oxide scale is more convoluted. At $1000^{\circ} \mathrm{C}$, in wet air, the scale is duplex. The outer scale corresponds to hematite. This oxide spalled off during cooling to room temperature and is not observed on the cross-section. The inner scale is multilayered and shows alternatively $\mathrm{FeCr}_{2} \mathrm{O}_{4}$ scales and non-oxidised metallic layers. Some silica particles are also identified inside this internal oxidation zone. The EDXS analyses performed in the metallic substrate, under the oxide scale, show that in the two first micrometre depth the chromium content is $14 \cdot 2 \pm 0 \cdot 3$ wt- $\%$. The $17 \cdot 7$ wt- $\%$ bulk content is reached $15 \mu \mathrm{m}$ deep inside the alloy. The surface alloy chromium ratio is the same whatever the temperature and gaseous environment. It then appears that water vapour does not lead to higher chromium depletion inside the substrate. Similar observations are still valid after 10 thermal cycles. The only difference observed is that at $1000^{\circ} \mathrm{C}$ in dry air the chromium content is slightly lower: $12 \cdot 8 \pm 0 \cdot 2 \mathrm{wt}-\%$ in the two first micrometre alloy depths, and the chromium depletion goes deeper $(40 \mu \mathrm{m})$. In moist air, the chromium content is $14 \cdot 5 \pm 0 \cdot 3 \mathrm{wt}-\%$ at the same alloy depth. After thermal cycling, water vapour does not promote chromium depletion inside the substrate due to a preferential inward oxidation process.
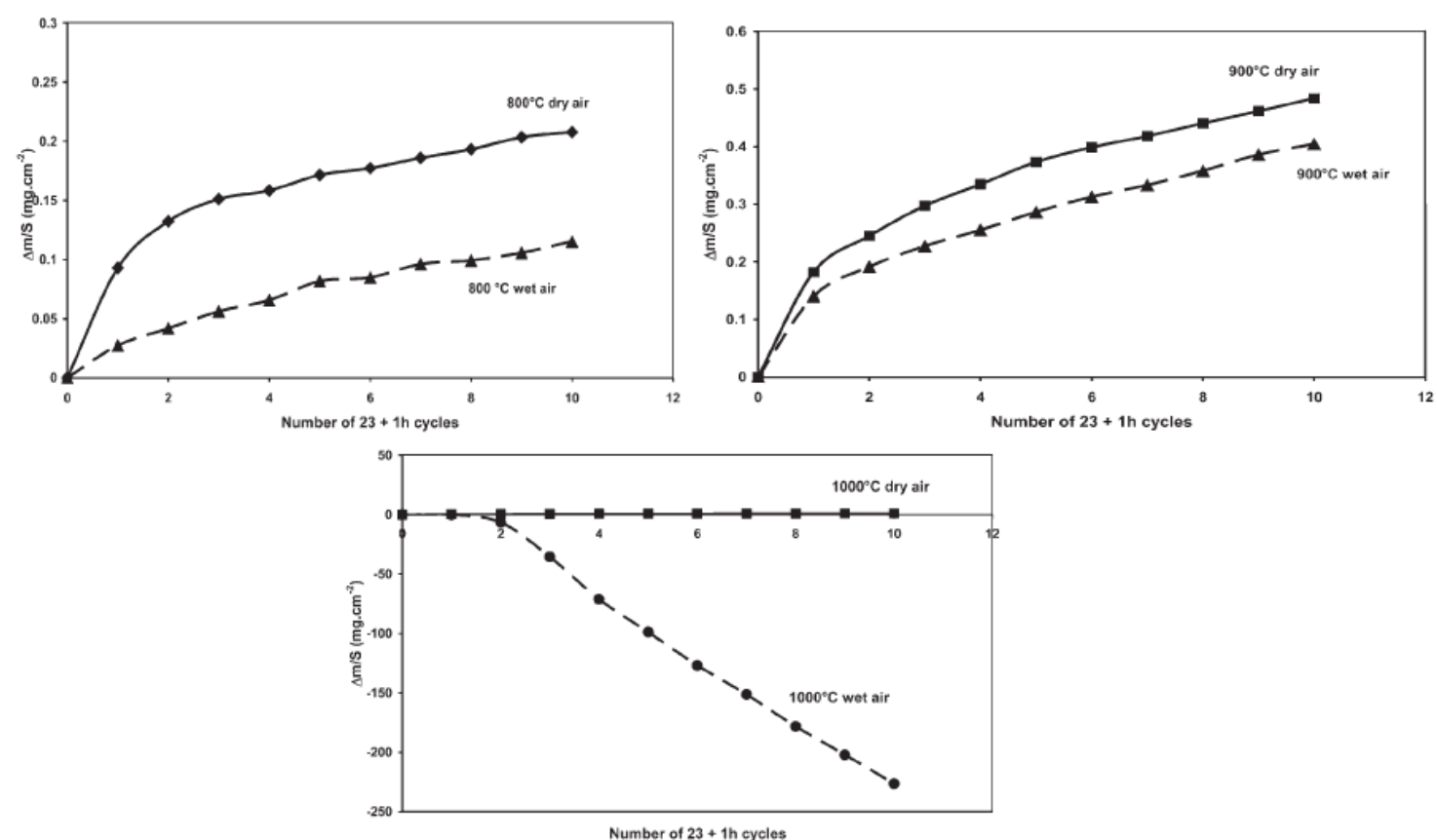

2 Mass gain curves obtained after thermal cycling oxidation $(23+1 \mathrm{~h})$ of AISI $316 \mathrm{~L}$ SS under dry air or wet air (10 vol.$\% \mathrm{H}_{2} \mathrm{O}$ ) at 800,900 and $1000^{\circ} \mathrm{C}$ 

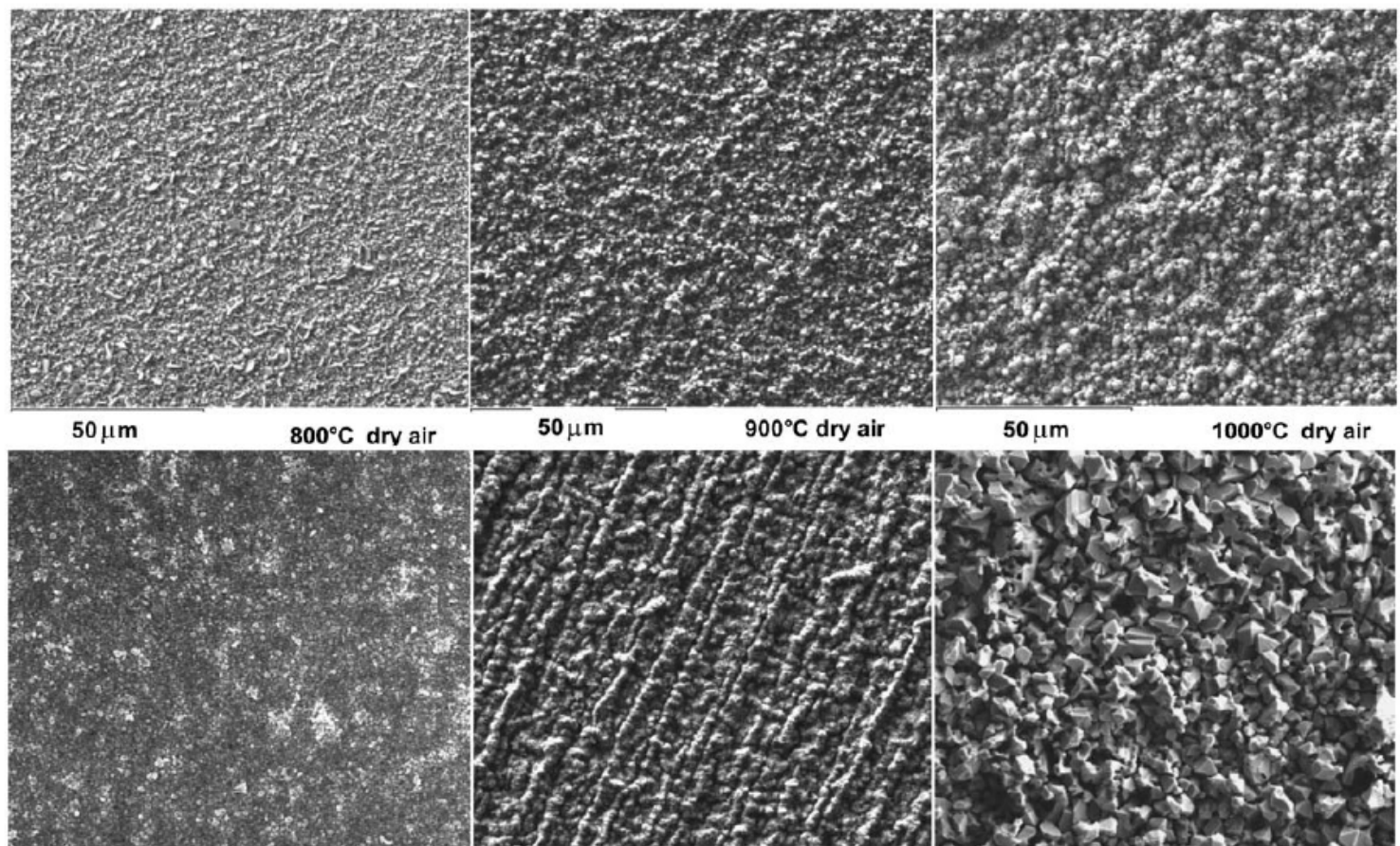

$50 \mu \mathrm{m}$

$900^{\circ} \mathrm{C}$ dry air

$50 \mathrm{um}$

$1000^{\circ} \mathrm{C}$ dry air
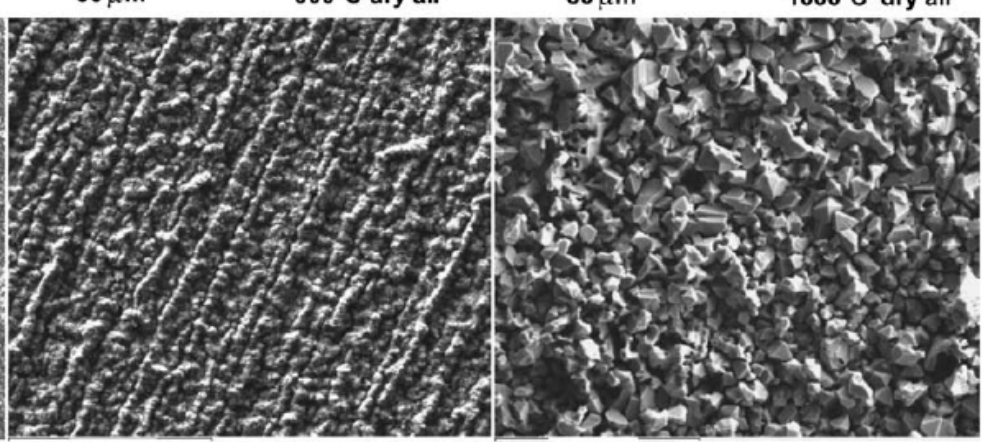

$50 \mu \mathrm{m} \quad 800^{\circ} \mathrm{C}$ air $+10 \mathrm{vol} . \% \mathrm{H}_{2} \mathrm{O}$

$\mathbf{5 0} \mu \mathrm{m}$

$900^{\circ} \mathrm{C}$ air +10 vol. $\% \mathrm{H}_{2} \mathrm{O}$

$50 \mu \mathrm{m}$

$1000^{\circ} \mathrm{C}$ air +10 vol. $\% \mathrm{H}_{2} \mathrm{O}$

3 Micrograph (SEM) showing structure of outer grains observed on AISI $316 \mathrm{~L}$ SS surface oxidised at 800 , 900 and $1000^{\circ} \mathrm{C}$ in dry air or wet air $\left(10\right.$ vol.- $\left.\% \mathrm{H}_{2} \mathrm{O}\right)$ for $96 \mathrm{~h}$

\section{X-ray diffraction results after isothermal oxidation}

The XRD patterns obtained from the AISI 316L SS sample after $96 \mathrm{~h}$ isothermal oxidation at 800,900 and $1000^{\circ} \mathrm{C}$ in dry air are shown in Fig. 5. It reveals the presence of $\mathrm{Mn}_{1.5} \mathrm{Cr}_{1 \cdot 5} \mathrm{O}_{4}$ [Joint Committee on Powder Diffraction Standards (JCPDS) no. 33-0892] and $\mathrm{Cr}_{2} \mathrm{O}_{3}$ (JCPDS no. 38-1479) after oxidation at all temperatures. The relative intensity of the alloys peaks is smaller at $1000^{\circ} \mathrm{C}$ due to the higher oxide thickness. After wet air oxidation, Fig. 6 exhibits the presence of $\mathrm{Mn}_{1.5} \mathrm{Cr}_{1.5} \mathrm{O}_{4}$ and $\mathrm{Cr}_{2} \mathrm{O}_{3}$ on the alloy surface after oxidation at 800 and $900^{\circ} \mathrm{C}$. At $1000^{\circ} \mathrm{C}$, the XRD analysis of the remaining oxide only shows the presence of $\mathrm{FeCr}_{2} \mathrm{O}_{4}$ (JCPDS no. 34-0140) because the external $\mathrm{Fe}_{2} \mathrm{O}_{3}$ scale totally spalled off during cooling.

\section{In situ XRD results in wet air at $1000^{\circ} \mathrm{C}$}

The oxide scale formed on the AISI $316 \mathrm{~L}$ SS was analysed by in situ XRD on the metallic substrate at $1000^{\circ} \mathrm{C}$ in wet air $\left(10\right.$ vol.- $\left.\% \mathrm{H}_{2} \mathrm{O}\right)$ during $65 \mathrm{~h}$ (Fig. 7). At $1000^{\circ} \mathrm{C}$, it was noted that the dilatation of the metallic structure induces a shift of the diffraction peaks of the AISI $316 \mathrm{~L}$ SS to the lower angle values. After cooling to room temperature, the alloy peaks were again normally placed. No shift was observed on the oxide peaks location due to the very low dilatation of the oxides. Figure 7 shows the presence of $\mathrm{Mn}_{1 \cdot 5} \mathrm{Cr}_{1 \cdot 5} \mathrm{O}_{4}$ (JCPDS no. 33-0892) and $\mathrm{Cr}_{2} \mathrm{O}_{3}$ (JCPDS no. 38-1479) during the first $31 \mathrm{~h}$ of oxidation. It appears that both oxides nucleate simultaneously on the specimen surface during the first hour of oxidation and remain together at the external interface. No other oxides were formed during the $31 \mathrm{~h}$ oxidation test. After $36 \mathrm{~h}$ oxidation, hematite $\mathrm{Fe}_{2} \mathrm{O}_{3}$ (JCPDS no. 24-0027) is detected on the alloy surface, and $\mathrm{Cr}_{2} \mathrm{O}_{3}$ peaks are still observed. After $65 \mathrm{~h}$ oxidation, the hematite scale is thick, and the $\mathrm{FeCr}_{2} \mathrm{O}_{4}$ inner oxide is hardly detected. After cooling to room temperature, Fig. 7 shows that the XRD pattern obtained does not show the presence of hematite anymore. $\mathrm{FeCr}_{2} \mathrm{O}_{4}$ and the alloy are the only phases observed on the diffraction pattern. This is due to the complete hematite scale spallation during cooling. After the in situ XRD testing, the pieces of the hematite scale were found in the bottom part of the high temperature chamber, out of the crucible. In situ XRD results at $1000^{\circ} \mathrm{C}$, in dry air, were already presented in a previous paper. ${ }^{13}$ It was shown that $\mathrm{Mn}_{1.5} \mathrm{Cr}_{1 \cdot 5} \mathrm{O}_{4}$ and $\mathrm{Cr}_{2} \mathrm{O}_{3}$ were detected on the alloy surface all along the oxidation test in dry air and after cooling to room temperature.

\section{Scale morphology after thermal cycling}

The morphology of the scale formed after 10 thermal cycles $(23+1 \mathrm{~h})$ in dry and wet air is presented in Fig. 8 . No scale spallation was observed on the surface after dry air oxidation between 800 and $1000^{\circ} \mathrm{C}$. Energy dispersive X-ray spectroscopy analysis of the sample surface shows the presence $\mathrm{Mn}_{1 \cdot 5} \mathrm{Cr}_{1 \cdot 5} \mathrm{O}_{4}$ and $\mathrm{Cr}_{2} \mathrm{O}_{3}$ identified by XRD. After wet air oxidation, the scale is still adherent at 800 and $900^{\circ} \mathrm{C}$. The surface oxide grains are two times smaller after wet oxidation. Energy dispersive $\mathrm{X}$-ray spectroscopy analysis of the sample surface shows the presence of manganese, chromium and oxygen at 800 and $900^{\circ} \mathrm{C}$. At $1000^{\circ} \mathrm{C}$, in dry air, EDXS analysis shows the presence of manganese, chromium and oxygen. At $1000^{\circ} \mathrm{C}$, in wet air, EDXS analysis shows the presence of iron, chromium and oxygen corresponding to $\mathrm{FeCr}_{2} \mathrm{O}_{4}$ formation. The SEM examinations were 

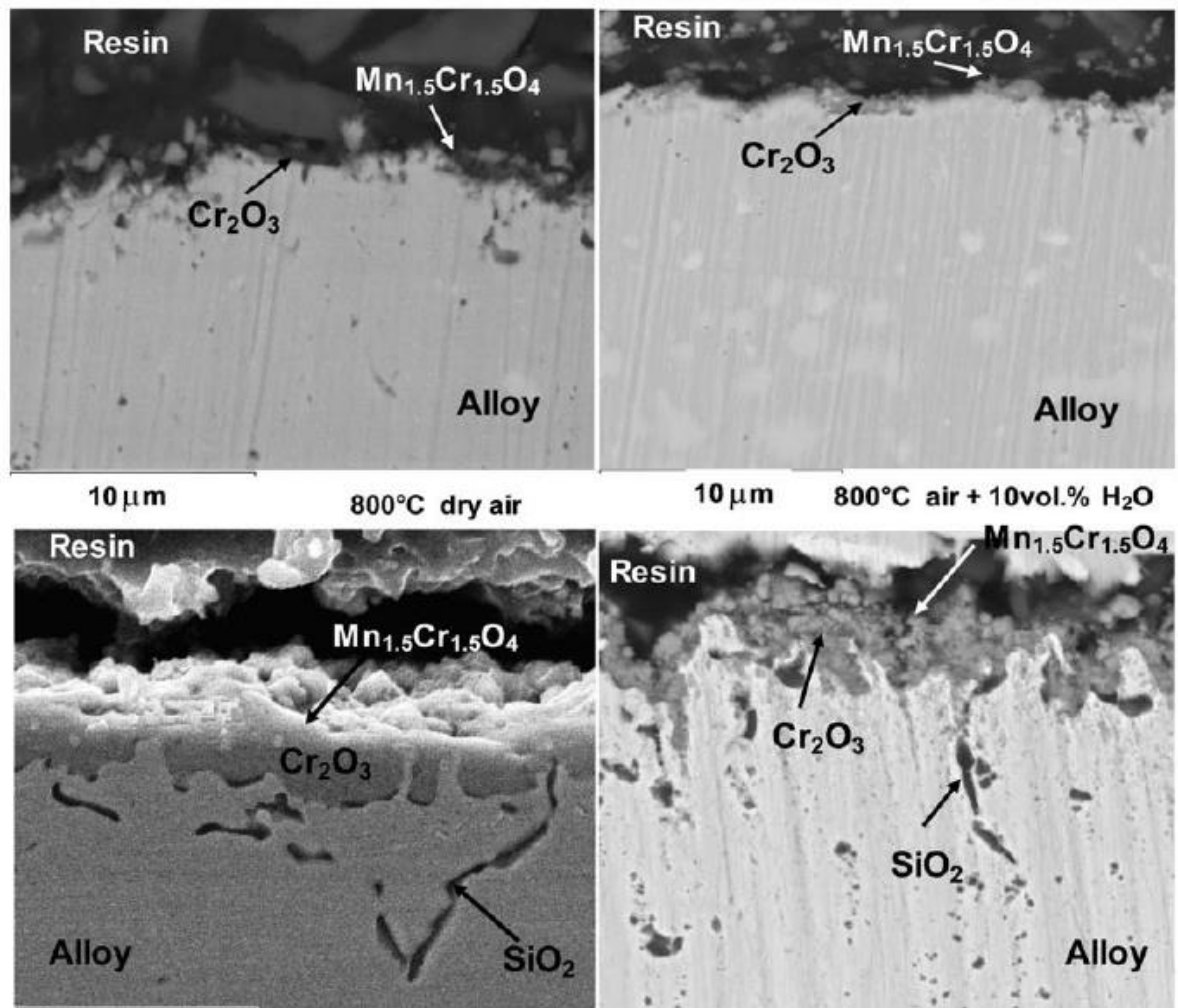

$10 \mu \mathrm{m} \quad 800^{\circ} \mathrm{C}$ air $+10 \mathrm{vol} \% \mathrm{H}_{2} \mathrm{O}$
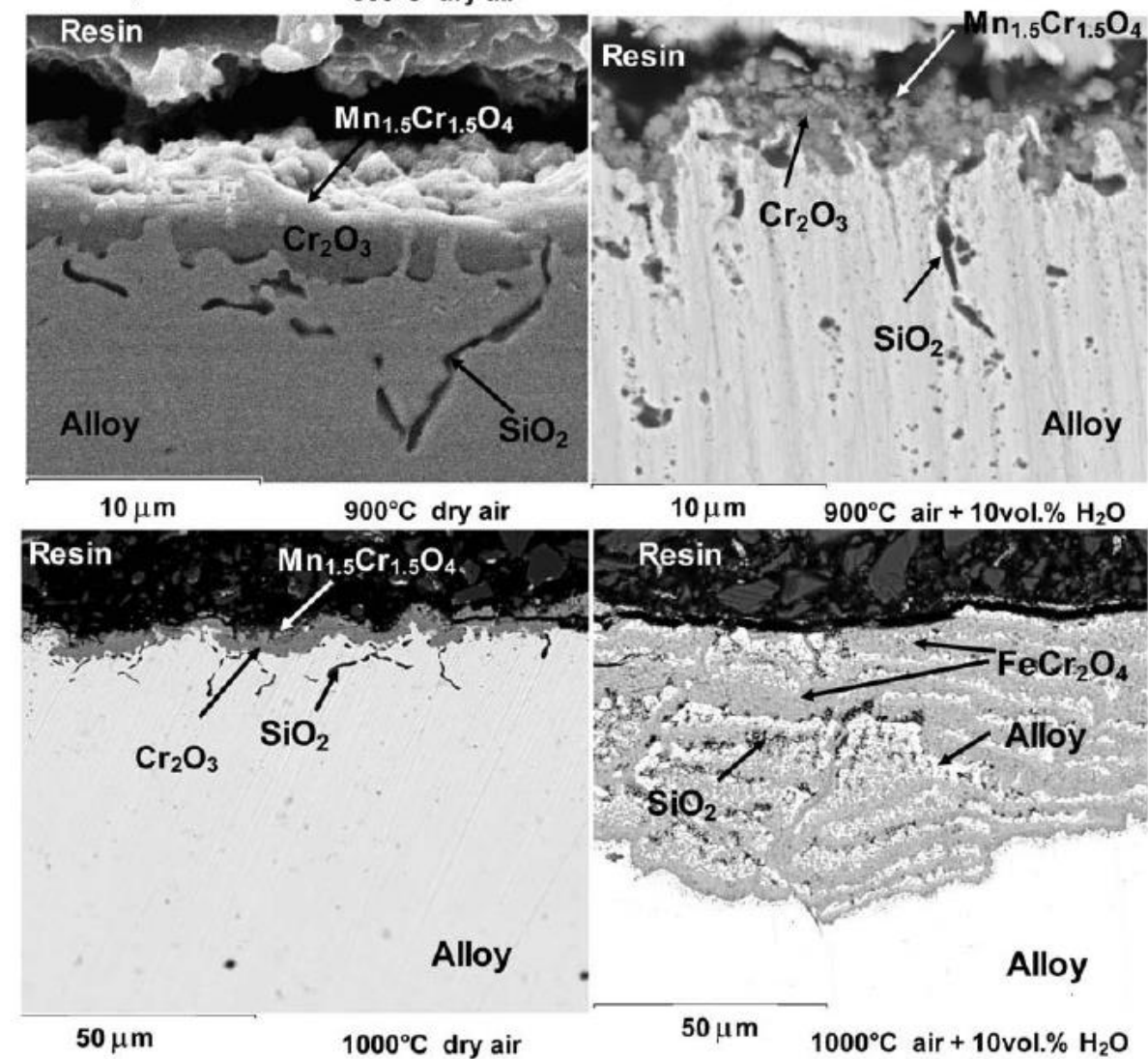

4 Cross-section (SEM) on AISI $316 \mathrm{~L}$ SS oxidised at 800,900 and $1000^{\circ} \mathrm{C}$ in dry air or wet air $\left(10\right.$ vol.- $\left.\% \mathrm{H}_{2} \mathrm{O}\right)$ for $96 \mathrm{~h}$

carried out on the specimen cross-sections (Fig. 9) after 10 cycles. Cyclic oxidation in dry air at 800,900 and $1000^{\circ} \mathrm{C}$ leads to adherent scales. The EDXS analyses performed on the cross-section show that manganese and chromium were located at the external interface. The middle part of the oxide scale is mainly composed of chromia. Internal silicon oxidation is observed along the alloy grain boundaries at 900 and $1000^{\circ} \mathrm{C}$. Water vapour does not influence the silicon internal oxidation process at low temperatures during thermal cycling. At $1000^{\circ} \mathrm{C}$, the oxide scale structure is different between dry and wet conditions. In dry air, the scale is adherent and still composed of $\mathrm{Mn}_{1 \cdot 5} \mathrm{Cr}_{1.5} \mathrm{O}_{4}$ and $\mathrm{Cr}_{2} \mathrm{O}_{3}$, after 10 cycles. In wet air, the scale is multilayered and shows alternatively $\mathrm{FeCr}_{2} \mathrm{O}_{4}$ scales and chromium depleted alloy layers. Silica particles are located inside the internal oxide zone. The hematite scale has spalled off after the second cycle and is not observable on the cross-section anymore. The weight losses registered after the second cycle are due to the exfoliation of $\mathrm{FeCr}_{2} \mathrm{O}_{4}$ particles.

\section{X-ray diffraction results after thermal cycling}

The XRD patterns obtained from the AISI 316L SS sample after 10 thermal cycles at 800,900 and $1000^{\circ} \mathrm{C}$ in dry air are shown in Fig. 10. It exhibits the presence of $\mathrm{Mn}_{1 \cdot 5} \mathrm{Cr}_{1 \cdot 5} \mathrm{O}_{4}$ (JCPDS no. 33-0892) and $\mathrm{Cr}_{2} \mathrm{O}_{3}$ (JCPDS no. 38-1479) after oxidation at all temperatures. After thermal cycling in wet air, Fig. 11 shows the presence of $\mathrm{Mn}_{1 \cdot 5} \mathrm{Cr}_{1 \cdot 5} \mathrm{O}_{4}$ and $\mathrm{Cr}_{2} \mathrm{O}_{3}$ on the alloy surface at 800 and $900^{\circ} \mathrm{C}$. At $1000^{\circ} \mathrm{C}, \mathrm{XRD}$ analysis of the remaining oxide shows the presence of $\mathrm{FeCr}_{2} \mathrm{O}_{4}$ (JCPDS no. 34-0140). The alloy particles observed on the SEM cross-section in the multilayered zone are also detected by XRD. 


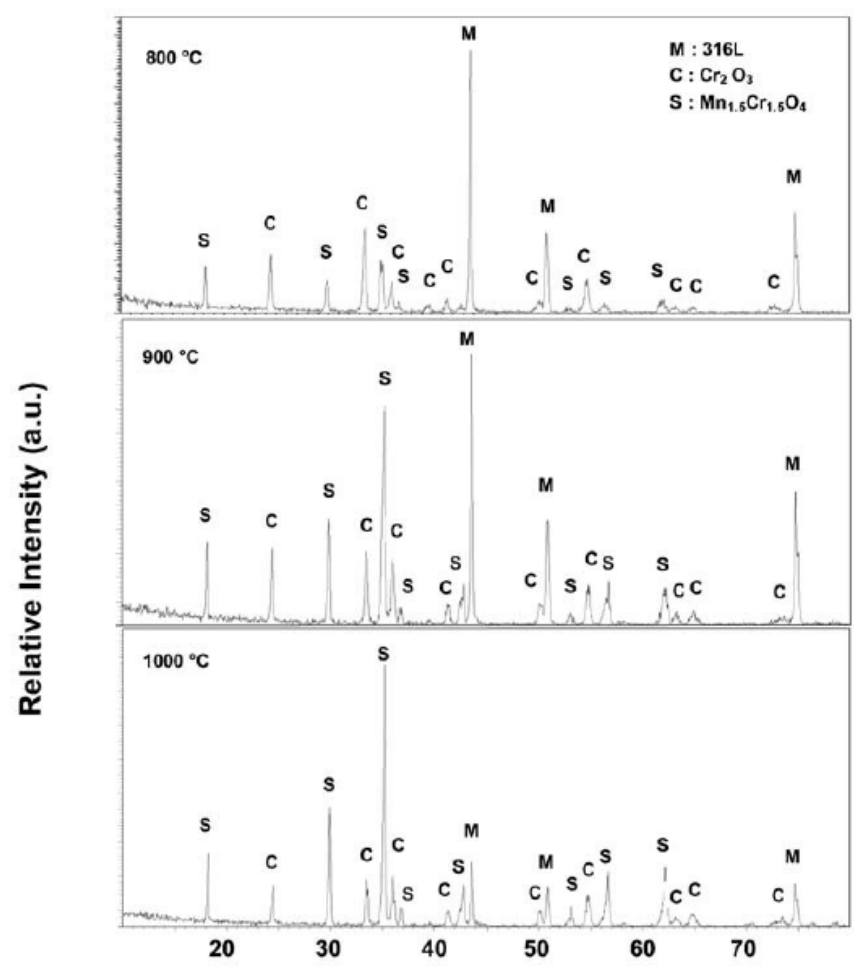

Diffraction Angle 2 Theta (degrees)

5 X-ray diffraction patterns obtained from AISI $316 \mathrm{~L} \mathrm{SS}$ sample after $96 \mathrm{~h}$ isothermal oxidation at 800,900 and $1000^{\circ} \mathrm{C}$ in dry air

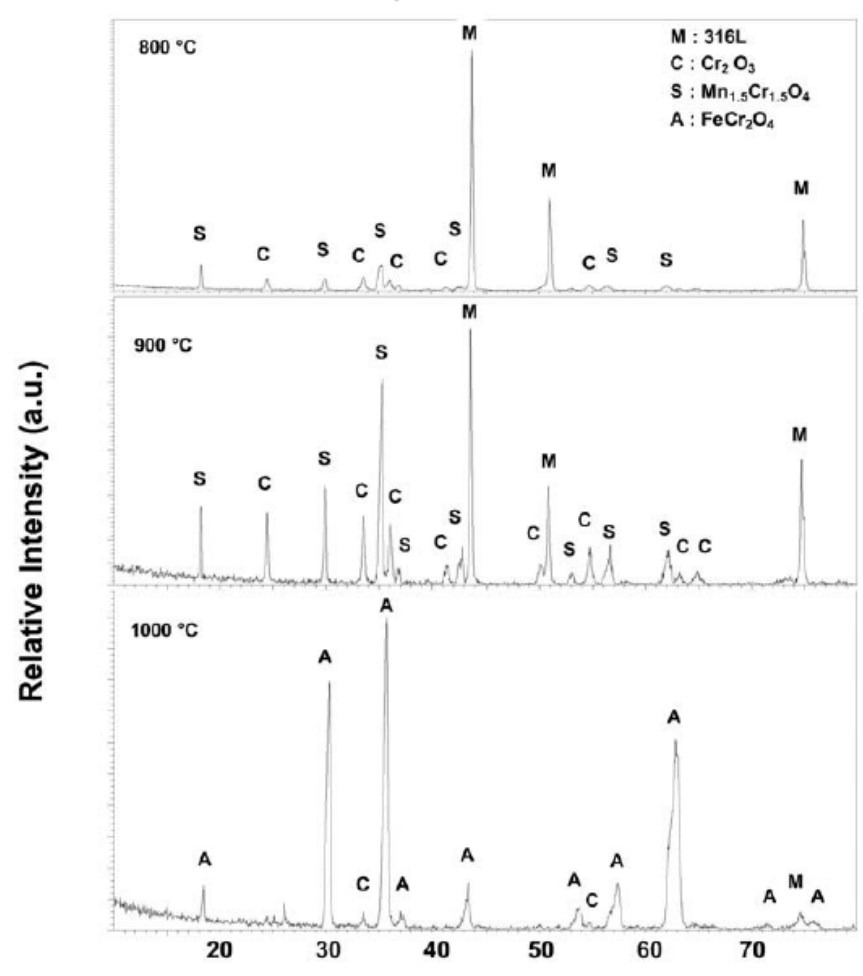

Diffraction Angle 2 Theta (degrees)

6 X-ray diffraction patterns obtained from AISI $316 \mathrm{~L}$ SS sample after $96 \mathrm{~h}$ isothermal oxidation at 800,900 and $1000^{\circ} \mathrm{C}$ in wet air $\left(10\right.$ vol.- $\left.\% \mathrm{H}_{2} \mathrm{O}\right)$ 


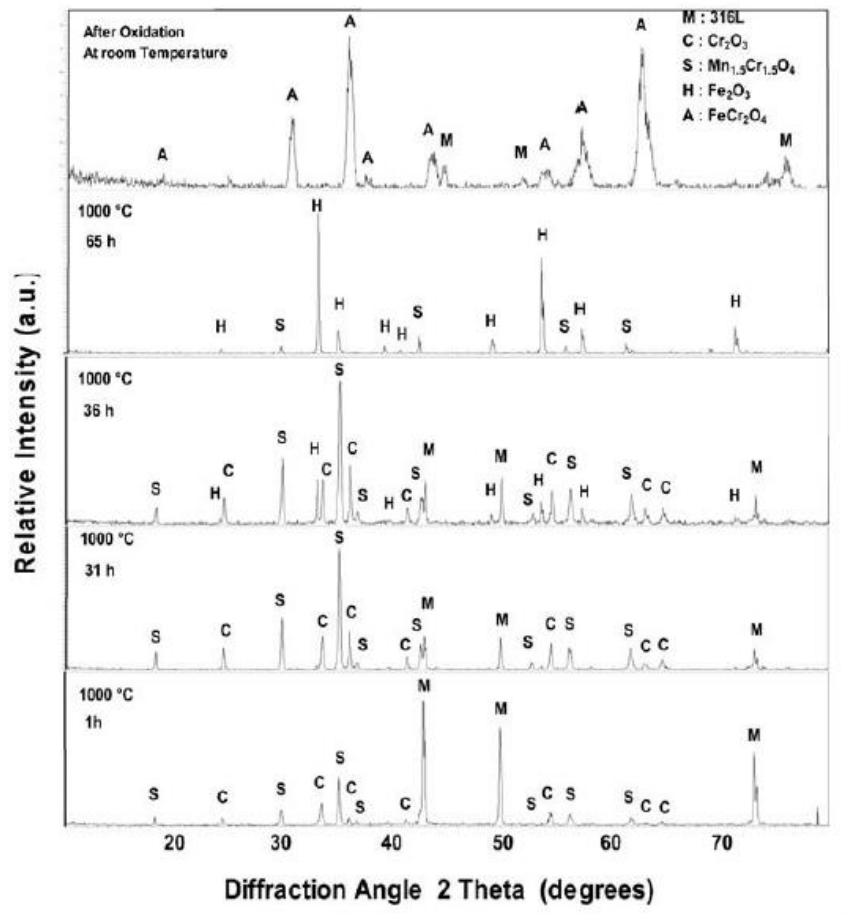

7 In situ XRD patterns obtained during oxidation of $316 \mathrm{~L}$ alloy at $1000^{\circ} \mathrm{C}$ under wet air $\left(10\right.$ vol.- $\left.\% \mathrm{H}_{2} \mathrm{O}\right)$

\section{Discussion}

\section{Effect of water vapour on oxidation rate}

Kinetic results have been obtained for AISI 316L SS between 800 and $1000^{\circ} \mathrm{C}$ under isothermal conditions
(Fig. 1). The parabolic behaviour was always followed in this temperature range under dry and wet conditions at 800 and $900^{\circ} \mathrm{C}$. This permitted the calculation of the parabolic rate constants $k_{\mathrm{p}}$ at each temperature (Table 1). The parabolic rate constant at $1000^{\circ} \mathrm{C}$ in

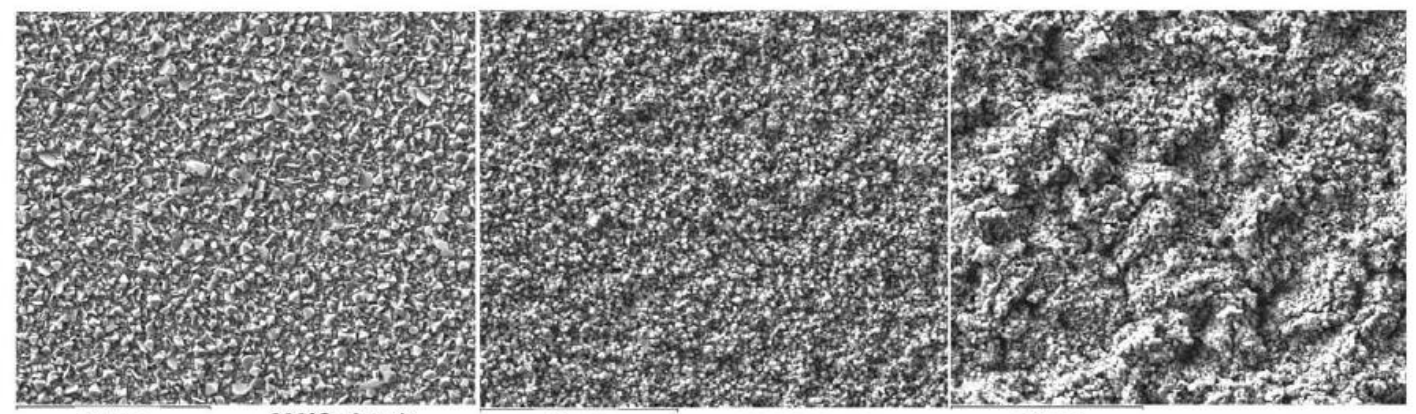

$\mathbf{5 0} \mu \mathrm{m}$ $800^{\circ} \mathrm{C}$ dry air $50 \mu \mathrm{m}$

$900^{\circ} \mathrm{C}$ dry air $50 \mu \mathrm{m}$

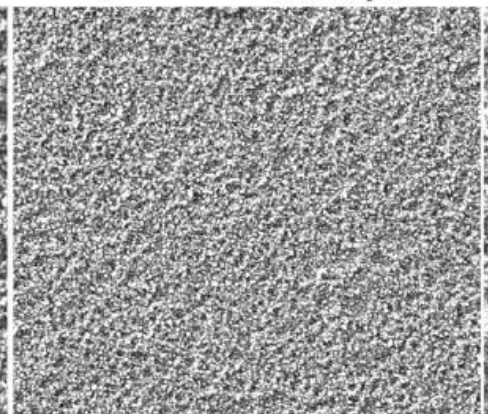

$50 \mu \mathrm{m} \quad 900^{\circ} \mathrm{C}$ air $+10 \mathrm{vol} . \% \mathrm{H}_{2} \mathrm{O}$

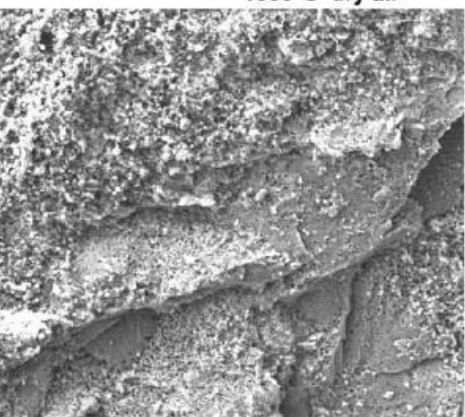

$50 \mu \mathrm{m} \quad 1000^{\circ} \mathrm{C}$ air $+10 \mathrm{vol} . \% \mathrm{H}_{2} \mathrm{O}$

8 Image (SEM) showing oxide surface structure on AISI $316 \mathrm{~L}$ SS surface oxidised after $10(23+1 \mathrm{~h})$ thermal cycles at 800,900 and $1000^{\circ} \mathrm{C}$ in dry air and wet air $\left(10\right.$ vol.- $\left.\% \mathrm{H}_{2} \mathrm{O}\right)$ 


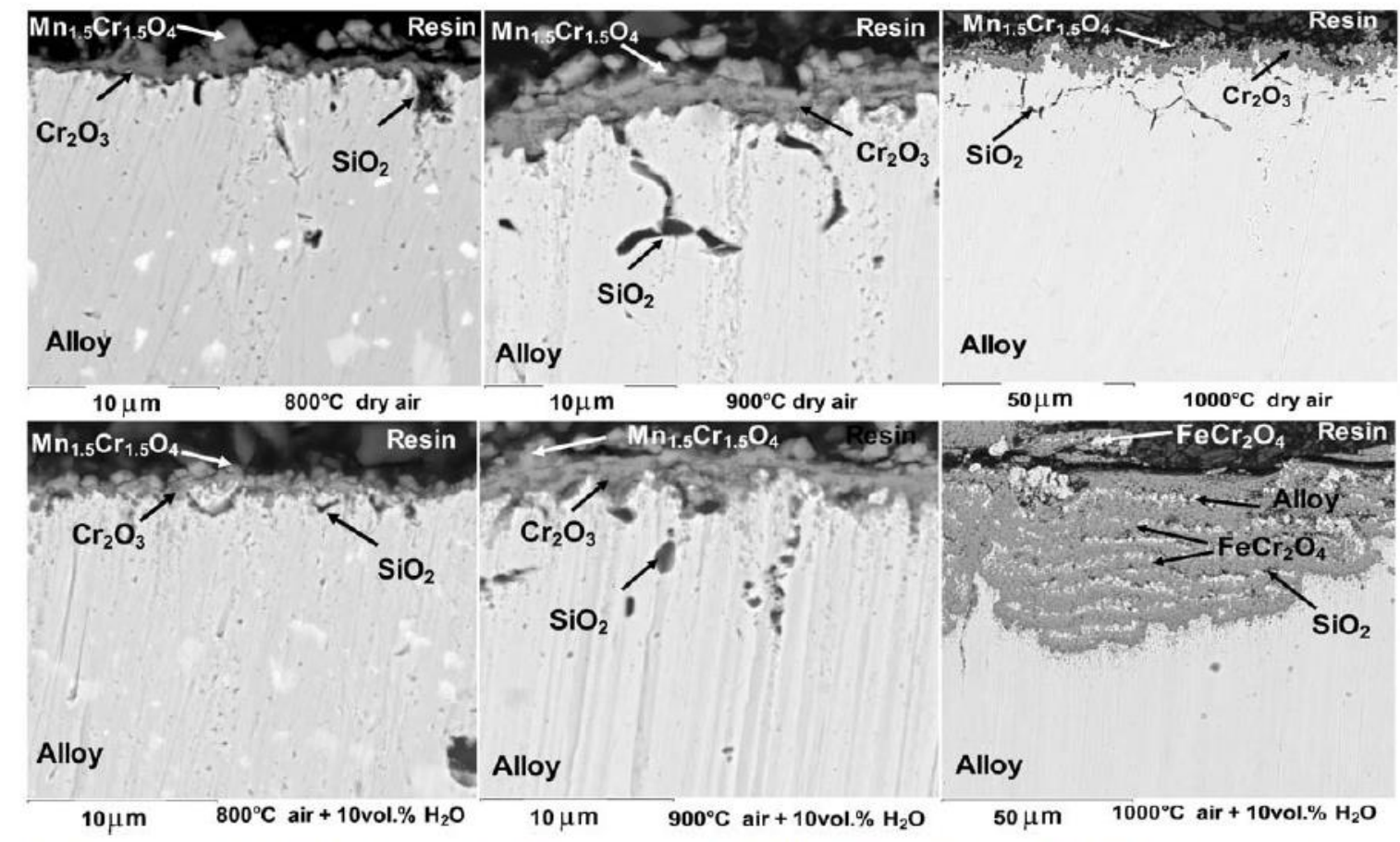

9 Cross-section (SEM) after $10(23+1 \mathrm{~h})$ cycles oxidation on AISI $316 \mathrm{~L}$ SS at 800,900 and $1000^{\circ} \mathrm{C}$ in dry air and wet air $\left(10\right.$ vol. $\left.-\% \mathrm{H}_{2} \mathrm{O}\right)$

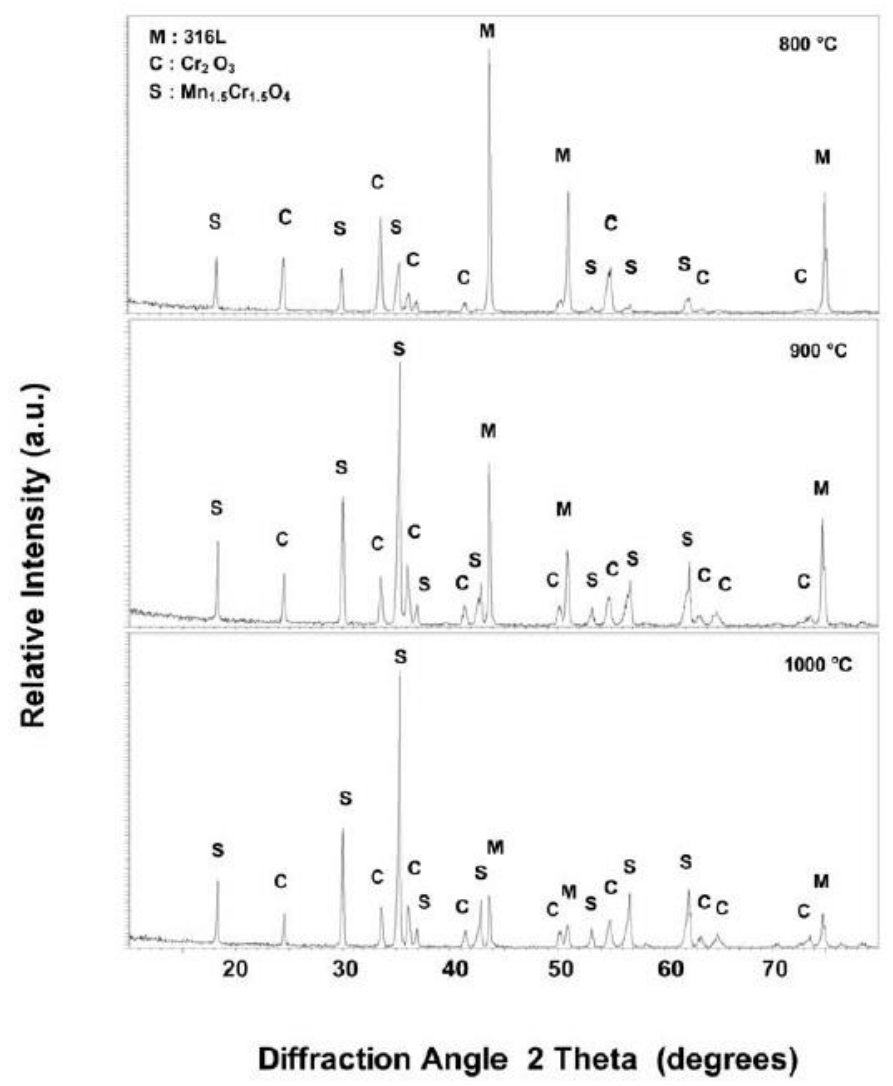

10 X-ray diffraction patterns obtained from AISI $316 \mathrm{~L}$ SS sample after 10 cycles $(23+1 \mathrm{~h})$ at 800,900 and $1000^{\circ} \mathrm{C}$ in dry air 


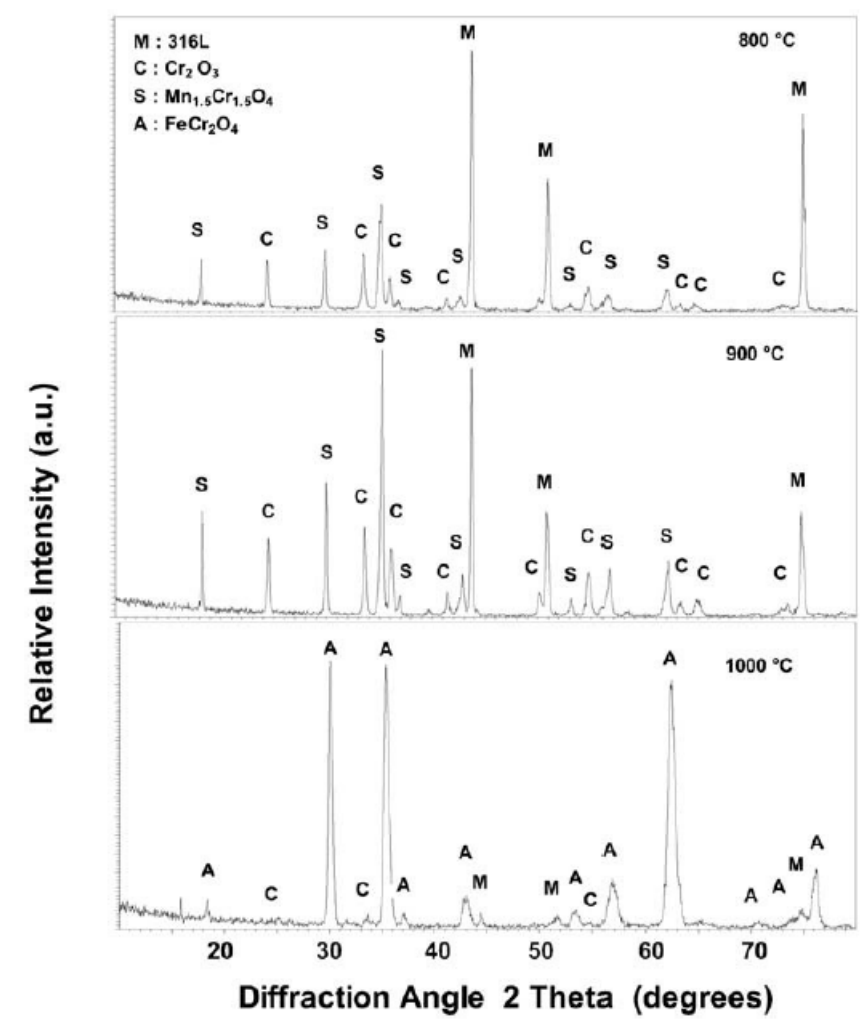

11 X-ray diffraction patterns obtained from AISI $316 \mathrm{~L}$ SS sample after 10 cycles $(23+1 \mathrm{~h})$ at 800,900 and $1000^{\circ} \mathrm{C}$ in wet air $\left(10\right.$ vol. $\left.\% \mathrm{H}_{2} \mathrm{O}\right)$

moist air was calculated from the kinetic curve obtained before $24 \mathrm{~h}$ oxidation. At $1000^{\circ} \mathrm{C}$, in dry air, the $k_{\mathrm{p}}$ value is calculated from the data obtained during $96 \mathrm{~h}$ oxidation. An apparent activation energy $E_{\mathrm{a}}$ was calculated from the slope of the Arrhenius plots of the $k_{\mathrm{p}}$ values, $E_{\mathrm{a}}=208 \pm 30 \mathrm{~kJ} \mathrm{~mol}^{-1}$ under dry conditions and $E_{\mathrm{a}}=241 \pm 30 \mathrm{~kJ} \mathrm{~mol}^{-1}$ in wet air. These values are close to the one generally proposed in the literature when $\mathrm{Cr}_{2} \mathrm{O}_{3}$ is formed on the alloys in this temperature range. ${ }^{32,35}$ The apparent activation energies are in good agreement with the SEM cross-section observation (Fig. 4), showing that the scale was mainly composed of a continuous chromia scale, acting as a diffusion barrier. According to SEM (Figs. 3 and 4) and XRD analyses (Figs. 5 and 6), the good kinetic behaviour at 800 and $900^{\circ} \mathrm{C}$, in dry and moist air, appears to be mainly due to the absence of iron in the scale. Figures 1 and 2 also show that water vapour slightly decreases the oxidation rate relative to those registered in dry conditions, and the apparent activation energy is higher in wet air. As proposed by other authors, it could be due to the weight losses related to the formation of volatile hydroxide $\mathrm{CrO}_{2}(\mathrm{OH})_{2} \cdot{ }^{28-30} \mathrm{On}$ the other hand, Young explained that in short term laboratory experiments at low temperatures, chromium volatilisation can usually be neglected, even in $\mathrm{O}_{2} / \mathrm{H}_{2} \mathrm{O}$ gas mixtures. ${ }^{31}$ Evaporation is supposed to lead to chromium depletion in the alloy, resulting in the formation of an iron rich non-protective scale. ${ }^{33}$ Nevertheless, the EDXS analyses performed in the alloy $2 \mu \mathrm{m}$ under the oxide scale show that water vapour does not induce a higher chromium depletion compared to dry air oxidation. The chromium ratio is

always $\sim 14$ wt- $\%$ whatever the oxidation temperature and water content. According to XRD and SEM-EDXS analyses (Figs. 3-7), it should be noticed that the presence of manganese chromite at the scale/gas interface can hinder the volatilisation of $\mathrm{CrO}_{2}(\mathrm{OH})_{2}$ under wet conditions, as it was proposed by some authors. ${ }^{24,36,37}$ Then, the lower oxidation rate is better due to a water vapour effect on the chromia scale growth mechanism. Some authors proposed that water segregates at oxide grain boundaries and cation diffusion is lowered, increasing the oxygen internal diffusion contribution. As proposed by Young, this effect is very similar to those attributed to reactive element metals on the diffusion process. ${ }^{38}$ As shown in Fig. 3, the convoluted aspect of the scale obtained at $900^{\circ} \mathrm{C}$ in moist air is very similar to what is obtained on chromia scale obtained on lanthanum sol gel coated chromia forming alloys. ${ }^{39}$ As proposed in the literature, a convoluted scale suggests that the cationic diffusion in chromia scale is lowered by the presence of lanthanum. ${ }^{40}$ This scale structure develops with time during the oxidation process and is not the result of a deformation during cooling to room temperature. ${ }^{41-44}$ The convolution is generally related to lateral growth in the chromia scale. ${ }^{45}$ It results from the formation of new oxide inside the chromia scale. It can also be due to the growth stresses generated inside the chromia scale, leading to a plastic deformation of the scale and the underlying metallic substrate.

\section{Water induced breakaway oxidation}

At $1000^{\circ} \mathrm{C}$, the scale remains protective during oxidation test in dry air (Figs. 1, 3 and 4). $\mathrm{Mn}_{1 \cdot 5} \mathrm{Cr}_{1 \cdot 5} \mathrm{O}_{4}$ and $\mathrm{Cr}_{2} \mathrm{O}_{3}$ 
are present all along the oxidation test. In wet air, oxidation at $1000^{\circ} \mathrm{C}$ firstly leads to $\mathrm{Mn}_{1 \cdot 5} \mathrm{Cr}_{1 \cdot 5} \mathrm{O}_{4}$ and $\mathrm{Cr}_{2} \mathrm{O}_{3}$ formation. Nevertheless, breakaway corrosion occurred after $31 \mathrm{~h}$ oxidation. In situ XRD permit to analyse the oxides formed on AISI 316L SS during isothermal oxidation at $1000^{\circ} \mathrm{C}$ in moist air (Fig. 7). The breakaway oxidation is due to the iron oxidation starting after $31 \mathrm{~h}$ oxidation. This leads to an external hematite scale growth and an internal multilayered $\mathrm{FeCr}_{2} \mathrm{O}_{4}$ scale formation. Some authors have observed that water vapour can induce a breakaway during high temperature oxidation of iron based chromia forming alloys. $^{20,23}$ Then, it was observed that it depends upon the oxidation time, testing conditions and chromium alloy content. ${ }^{23}$ As discussed above, chromium volatilisation by the formation oxy-hydroxides $\mathrm{CrO}_{2}(\mathrm{OH})_{2}$ can be neglected. ${ }^{46,47}$ For a low chromium content $(9 \% \mathrm{Cr}$ steels), Ehlers et al. suggested that volatile $\mathrm{Fe}(\mathrm{OH})_{2}$ forms at low $\mathrm{p}\left(\mathrm{O}_{2}\right)$ in the inner layers of the scale and is then converted to hematite or magnetite in the outer layer of the scale. ${ }^{48}$ This explanation cannot be given in the present work because the AISI $316 \mathrm{~L} \mathrm{SS}$ is $17 \cdot 7 \% \mathrm{Cr}$ rich and a high $\mathrm{p}\left(\mathrm{O}_{2}\right)$ is maintained. Our work can be more related to that of Galerie et al., who have shown that the first stage of breakaway of $\mathrm{Fe}-15 \mathrm{Cr}$ at 800 $1000^{\circ} \mathrm{C}$ in $\mathrm{Ar}-15 \mathrm{H}_{2} \mathrm{O}$ corresponds to the separation of chromia scale from alloy and inward gas diffusion allows the formation of hematite at the metal/oxide interface. $^{23}$ The rapid growth of hematite at this interface disrupts chromia scale and breakaway occurred. The high rate of oxidation was related to the water dissociation effect. Cheng et al. proposed that nickel particles located in the multilayered oxide scale could catalyse the water dissociation. ${ }^{49}$ Mikkelsen and Linderot explained the breakaway oxidation of $\mathrm{Fe}-22 \mathrm{Cr}$ at $800^{\circ} \mathrm{C}$ in an $\mathrm{H}_{2} / \mathrm{Ar}$ gas mixture (7:93) with the addition of $12 \%$ water vapour as a consequence of the stability of fast growing wüstite. ${ }^{50}$ Jianian et al. proposed that the failure of a protective chromia scale is the result of through scale cracking, which then leads to water vapour presence at the alloy/scale interface, where it reacts with the alloy forming $\mathrm{Fe}_{2} \mathrm{O}_{3}$ and $\mathrm{H}_{2}{ }^{27}$ Essuman et al. indicated that internal oxidation of chromium occurred inside the alloy. ${ }^{20,21}$ Solubility or diffusivity of oxygen in the alloy could be improved by water vapour. Our EDXS analyses do not show any higher oxygen solubility in the alloy, even after ten $23+1 \mathrm{~h}$ cycles in wet air. Some authors have explained the transport of $\mathrm{H}_{2} \mathrm{O}$ into the oxide scale by the diffusion of hydrogen as $\mathrm{H}^{+}$and/or $\mathrm{H}_{2} \mathrm{O}$ in the oxide scale. ${ }^{51,52}$ At $1000^{\circ} \mathrm{C}$, under wet air, manganese chromite and chromia were observed during the initial oxidation stage. Nevertheless, after $\sim 31 \mathrm{~h}$ oxidation, the protective chromia scale fails and breakaway appeared. It is proposed that water dissociation occurred on the specimen surface. ${ }^{23,49,53}$ This dissociation is more important at $1000^{\circ} \mathrm{C}$ than at lower temperature because water dissociation is endothermic. Then, the diffusion of hydrogen containing species could occur. Transport of $\mathrm{H}_{2} \mathrm{O}$ into the oxide scales is performed by the incorporation of hydrogen in the form of $\mathrm{H}^{+}$or $\mathrm{H}_{2} \mathrm{O} .{ }^{51,52,54} \mathrm{It}$ is assumed that protons $\left(\mathrm{H}^{+}\right)$from water vapour might dissolve in the oxides and diffuse at grain boundaries. Essuman et al. proposed a model to explain the internal oxidation of chromium alloys. ${ }^{20,21}$ Ardigo et al. performed gold and deuterium marking experiments and have evidenced that $\mathrm{Fe}_{3} \mathrm{O}_{4}$ and $\mathrm{Cr}_{2} \mathrm{O}_{3}$ scales are permeable to hydrogen. ${ }^{55}$ The low $\mathrm{H}^{+}$and $\mathrm{OH}^{-}$radii permit their diffusion through the oxide scale. Then, the increase in protons in the scale changes the oxide defect chemistry and could be responsible for the change in the growth mechanism. It can then be considered that the reaction of $\mathrm{H}^{+}$(and/or $\mathrm{H}_{2} \mathrm{O}$ ) with the metallic substrate under the chromia scale forms $\mathrm{H}_{2}$ and wüstite. ${ }^{46,47}$ Thermodynamic data indicate that, at $1000^{\circ} \mathrm{C}$, wüstite is more stable than $\mathrm{H}_{2} \mathrm{O}$. This is confirmed by Galerie et al., who have already observed wüstite formation under a chromia scale. ${ }^{23}$ Mikkelsen and Linderot also explained that the addition of water vapour favours the formation of wüstite. ${ }^{50}$ When $\mathrm{FeO}$ and chromia are present together, they react to form $\mathrm{FeCr}_{2} \mathrm{O}_{4}$. As observed by in situ XRD (Fig. 7), iron ions also diffuse through the scale to form $\mathrm{Fe}_{2} \mathrm{O}_{3}$ at the external interface, then inducing the breakaway oxidation.

\section{Influence of water vapour on scale adherence}

At 800 and $900^{\circ} \mathrm{C}$, thermal cycling kinetic curves and SEM-XRD results (Figs. 8-11) show that water vapour does not promote scale spallation. The SEM crosssection examinations show that a keying effect between the scale and the metallic matrix is due to the growth of internal oxide protrusions (Figs. 10 and 11). Our results are in accordance with those of Sobral et al., who studied the AISI 316L oxidation between 700 and $900^{\circ} \mathrm{C} .{ }^{8}$ These authors have also shown the presence of $\left(\mathrm{Mn}_{1.5} \mathrm{Cr}_{1.5}\right) \mathrm{O}_{4}$ and $\mathrm{Cr}_{2} \mathrm{O}_{3}$ after long exposure tests at $900^{\circ} \mathrm{C}$. The lower mass gain registered in Fig. 2 has been interpreted in a previous section as a result of a lower cation grain boundary diffusion. An indication of the modification in the scale growth process is also given by the surface oxide grain size, which is two times lower in wet air compared to dry air after 10 thermal cycles. Zurek et al. explains the water vapour effect by a change in the scale grain size and growth mechanism. ${ }^{56}$ As proposed by other authors, the oxide scale adherence can be improved in wet environments due to a smaller grain size and increased plastic deformations. ${ }^{32,57,58}$ As proposed above, water segregation at oxide grain boundaries can also lower cation diffusion and then increase the oxygen internal diffusion contribution. Both grain refinement and change in the growth mechanism explain that at 800 and $900^{\circ} \mathrm{C}, 10$ vol. $-\% \mathrm{H}_{2} \mathrm{O}$ has no detrimental effect on the scale adherence.

At $1000^{\circ} \mathrm{C}$, the scale adherence is still good after 10 cycles in dry air conditions. The EDXS analyses performed on the cross-section show that manganese and chromium were located at the external interface. In wet air, Fig. 2 shows that very important weight losses are registered after the second $(23+1 \mathrm{~h})$ cycle. It should be noticed that two cycles correspond to $46 \mathrm{~h}$ oxidation. This is more than the $31 \mathrm{~h}$ oxidation preceding the breakaway oxidation and iron oxide formation observed during the in situ XRD analyses (Fig. 7). The SEM examinations were carried out on the specimen crosssection (Fig. 9) after 10 cycles. In wet air, the scale is multilayered and shows alternatively $\mathrm{FeCr}_{2} \mathrm{O}_{4}$ scales and chromium depleted alloy layers. Silica particles are also present inside this internal oxide zone. The hematite scale has spalled off after the second cycle and the following weight losses are due to the spallation of the $\mathrm{FeCr}_{2} \mathrm{O}_{4}$ particles. The bad adherence of the scale 
formed in wet air at $1000^{\circ} \mathrm{C}$ is clearly related to iron oxidation starting after only $31 \mathrm{~h}$ in 10 vol. $-\% \mathrm{H}_{2} \mathrm{O}$ containing air. The breakaway oxidation mechanism is the same described for isothermal oxidation conditions. It implies the reaction of $\mathrm{H}^{+}$(and/or $\mathrm{H}_{2} \mathrm{O}$ ) with the metallic substrate under the chromia scale to form $\mathrm{H}_{2}$ and iron oxides.

\section{Conclusion}

In situ XRD was used to identify the oxides formed on the AISI $316 \mathrm{~L} \mathrm{SS}$ during isothermal oxidation at $1000^{\circ} \mathrm{C}$ in moist air $\left(10\right.$ vol. $\left.-\% \mathrm{H}_{2} \mathrm{O}\right)$. Our results showed the presence of $\mathrm{Mn}_{1 \cdot 5} \mathrm{Cr}_{1 \cdot 5} \mathrm{O}_{4}$ and $\mathrm{Cr}_{2} \mathrm{O}_{3}$ chromia growing simultaneously on the specimen surface before $31 \mathrm{~h}$ oxidation. After $31 \mathrm{~h}$ oxidation, $\mathrm{Fe}_{2} \mathrm{O}_{3}$ is growing on the specimen surface at the external interface, and internal corrosion leads to a multilayered $\mathrm{FeCr}_{2} \mathrm{O}_{4}$ scale. Hematite, located at the external interface, spalled off easily during cooling to room temperature. At 800 and $900^{\circ} \mathrm{C}, 10$ vol. $-\% \mathrm{H}_{2} \mathrm{O}$ in air has no detrimental effect on the AISI 316L SS isothermal oxidation and after 10 thermal cycles $(23+1 \mathrm{~h})$. The oxide scale is always composed of $\mathrm{Cr}_{2} \mathrm{O}_{3}$ with a small amount of $\mathrm{Mn}_{1,5} \mathrm{Cr}_{1,5} \mathrm{O}_{4}$ at the external interface. Results show that water molecules or protons can modify the diffusion processes in the scale. It then lowers the oxidation rate and modifies the scale structure. At $1000^{\circ} \mathrm{C}$, water vapour promotes iron oxidation.

\section{References}

1. J. E. Indacochea, J. L. Smith, K. R. Litko, E. J. Karell, A. G. Raraz: Oxid. Met., 2001, 55, 1-15.

2. A. L. Johnson, D. Parsons, J. Manzerova, D. L. Perry, D. Koury, B. Hosterman and J. W. Farley: J. Nucl. Mater., 2004, 328, 88-96.

3. J. Pitter, F. Cerny, J. Cizner, J. Suchanek and D. Tischler: Surf. Coat. Technol, 2005, 200, 73-76.

4. A. A. Syed, T. A. Denoirjean, P. Fauchais and J. C. Labbe: Surf. Coat. Technol., 2006, 20, 4368-4382

5. C. Vernault and J. Mendez: Ann. Chim. Sci. Mater., 1999, 24, 351362 .

6. X. Wang, L. F. Wang, M. L. Zhu, J. S. Zhang and M. K. Lei: Trans. Nonferr. Met. Soc. China, 2006, 16, s676-s680.

7. S.-G. Kim, M.-Z. Hong, S. P. Yoon, J. Han, S. W. Nam, T. H. Lim and S.-A. Hong: J. Sol-Gel Sci. Technol, 2003, 28, 297-306.

8. A. V. C. Sobral, M. P. Hierro, F. J. Pérez, W. Ristow, Jr. and C. V. Franco: Mater. Corros., 2000, 51, 791-796.

9. R. Singh and N. B. Dahotre: J. Mater. Sci., 2005, 40, 5619-5626.

10. P. N. S. Stokes, F. H. Stott and G. C. Wood: Mater. Sci. Eng., 1989, A121, 549-554

11. A. Bautista, F. Velasco, M. Campos, M. E. Rabanal and J. M Torralba: Oxid. Met., 2003, 59, 373-393.

12. A. Bautista, F. Velasco and J. Abenojar: Corros. Sci, 2003, 45, 1343-1354.

13. H. Buscail, S. El Messki, F. Riffard, S. Perrier, R. Cueff, E Caudron and C. Issartel: Mater. Chem. Phys., 2008, 111, 491-496.

14. H. Buscail, S. El Messki, F. Riffard, S. Perrier, R. Cueff and C. Issartel: J. Mater. Sci., 2008, 43, 6960-6966.

15. H. Buscail, S. El Messki, F. Riffard, S. Perrier and C. Issartel: Oxid. Met. 2011, 75, 27-39.

16. L. Antoni: Mater. Sci. Forum, 2004, 461-464, 1073-1090.

17. S. Fontana, S. Chevalier and G. Caboche: J. Power Sources, 2009 , 193, 136-145.

18. S. R. J. Saunders, M. Monteiro and F. Rizzo: Prog. Mater. Sci. $2008,53,775-837$.

19. H. Buscail, S. Heinze, P. Dufour and J. P. Larpin: Oxid. Met., 1997, 47, 445-464.
20. E. Essuman, G. H. Meier, J. Zurek, M. Hänsel, L. Singheiser and W. J. Quadakkers: Scr. Mater., 2007, 57, 845-848.

21. E. Essuman, G. H. Meier, J. Zurek, M. Hänsel, T. Norby, L. Singheiser and W. J. Quadakkers: Corros. Sci, 2008, 50, 17531760

22. D. L. Douglass, P. Kofstad, A. Rahmel and G. C. Wood: Oxid Met., 1996, 45, 529-621.

23. A. Galerie, S. Henry, Y. Wouters, M. Mermoux, J. P. Petit and L. Antoni: Mater. High Temp., 2005, 22, 105-112.

24. G. R. Holcomb and D. E. Alman: Scr. Mater., 2006, 54, 1821 1825 .

25. Y. Wouters, G. Bamba, A. Galerie, M. Mermoux and J. P. Petit: Mater. Sci. Forum, 2004, 461-464, 839-846.

26. H. Asteman, J. E. Svensson and L. G. Johansson: Oxid. Met. 2002 , 57, 193-216.

27. J. Shen, L. Zhou and T. Li: Oxid. Met., 1997, 48, 347-356.

28. E. J. Opila: Mater. Sci. Forum, 2004, 461-464, 765-774.

29. X. Peng, J. Yan, Y. Zhou and F. Wang: Acta Mater., 2005, 53, 5079-5088.

30. M. Schütze, D. Renusch and M. Schorr: Mater. High Temp., 2005, 22, 113-120

31. D. J. Young: Mater. Sci. Forum, 2008, 595-598, 1189-1197.

32. Y. P. Jacob, V. A. C. Haanappel, M. F. Stroosnijder, H. Buscail, P. Fielitz and G. Borchardt: Corros. Sci., 2002, 44, 2027-2039.

33. N. K. Othman, N. Othman, J. Zhang and D. J. Young: Corros Sci., 2009, 51, 3039-3049.

34. R. Rolland, C. Issartel, S. Perrier and H. Buscail: Corros. Eng. Sci. Technol., 2011, 46, 634-641.

35. J. H. Chen, P. M. Rogers and J. A. Little: Oxid. Met., 1997, 47, $381-410$.

36. V. P. Deodeshmukh: Oxid. Met., 2013, 79, 567-578.

37. D. Schmidt, M. Galetz and M. Schütze: Oxid. Met., 2013, 79, 589 599.

38. D. J. Young: 'High temperature oxidation and corrosion of metals', in 'Elsevier corrosion series', (ed. T. Burstein), 492, Vol. 1; 2008, Amsterdam, Elsevier.

39. H. Buscail, C. Issartel, F. Riffard, R. Rolland, S. Perrier, A. Fleurentin and C. Josse: Appl. Surf. Sci., 2011, 258, 678-686.

40. B. A. Pint: Oxid. Met., 1996, 45, 1-37.

41. F. H. Stott and G. C. Wood: Mater. Sci. Eng., 1987, 87, 267-274.

42. F. H. Stott, G. C. Wood and J. Stringer: Oxid. Met., 1995, 44, 113 145 .

43. R. G. Miner and V. Nagarajan: Oxid. Met., 1981, 16, 313-325.

44. V. K. Tolpygo and D. R. Clarke: Acta. Mater., 1998, 46, 5153 5166.

45. F. A. Golightly, G. C. Wood and F. H. Stott: Oxid. Met., 1980, 14, 217-234.

46. N. K. Othman, N. Othman, J. Zhang and D. J. Young: Corros. Sci., 2009, 51, 3039-3049.

47. N. K. Othman, J. Zhang and D. J. Young: Corros. Sci., 2010, 52 , 2827-2836.

48. J. Ehlers, D. J. Young, E. J. Smaardijk, A. K. Tyagi, H. J. Penkalla, L. Singheiser and W. J. Quadakkers: Corros. Sci., 2006, 48, 3428-3454.

49. S.-Y. Cheng, S.-L. Kuan and W.-T. Tsai: Corros. Sci., 2006, 48 , 634-649.

50. L. Mikkelsen and S. Linderot: Mater. Sci. Eng. A, 2003, A361, 198 212 .

51. A. Galerie, Y. Wouters and M. Caillet: Mater. Sci. Forum, 2001, 369-370, 231-238.

52. T. Norby: Am. Ceram. Soc., 1987, 23, 107-123.

53. C. Issartel, H. Buscail, Y. Wang, R. Rolland, M. Vilasi and L. Aranda: Oxid. Met., 2011, 76, 127-147.

54. T. Norby: J. Phys. IV , 1993, 3, 99-106.

55. M. R. Ardigo, I. Popa, S. Chevalier, S. Weber, O. Heintz and M Vilasi: Oxid. Met., 2013, 79, 495-505.

56. J. Zurek, D. J. Young, E. Essuman, M. Hansel, H. J. Penkalla, L. Niewolak and W. J. Quaddakers: Mater. Sci. Eng. A, 2008, A477, 259-270.

57. A. Rahmel and J. Tobolski: Corros. Sci, 1965, 5, 333-346.

58. C. W. Tuck, M. Odgers and K. Sachs: Corros. Sci., 1969, 9, 271 285 